University of Nebraska - Lincoln

DigitalCommons@University of Nebraska - Lincoln

\title{
Identification of Francisella tularensis subsp. tularensis A1 and A2 Infections by Real-Time Polymerase Chain Reaction
}

Claudia R. Molins

Division of Vector-Borne Infectious Diseases, Centers for Disease Control and Prevention, Fort Collins, CO

Jennifer K. Carlson

Division of Vector-Borne Infectious Diseases, Centers for Disease Control and Prevention, Fort Collins, CO

Jana Coombs

Utah Department of Health, Salt Lake City, UT 84113, USA

Jeannine M. Petersen

Division of Vector-Borne Infectious Diseases, Centers for Disease Control and Prevention, Fort Collins, CO

Follow this and additional works at: https://digitalcommons.unl.edu/publichealthresources

Part of the Public Health Commons

Molins, Claudia R.; Carlson, Jennifer K.; Coombs, Jana; and Petersen, Jeannine M., "Identification of Francisella tularensis subsp. tularensis A1 and A2 Infections by Real-Time Polymerase Chain Reaction" (2009). Public Health Resources. 64.

https://digitalcommons.unl.edu/publichealthresources/64

This Article is brought to you for free and open access by the Public Health Resources at DigitalCommons@University of Nebraska - Lincoln. It has been accepted for inclusion in Public Health Resources by an authorized administrator of DigitalCommons@University of Nebraska - Lincoln. 


\title{
Identification of Francisella tularensis subsp. tularensis A1 and A2 infections by real-time polymerase chain reaction
}

\author{
Claudia R. Molins ${ }^{\mathrm{a}}$, Jennifer K. Carlson ${ }^{\mathrm{a}}$, Jana Coombs ${ }^{\mathrm{b}}$, Jeannine M. Petersen ${ }^{\mathrm{a}, *}$ \\ ${ }^{\mathrm{a} D i v i s i o n}$ of Vector-Borne Infectious Diseases, Centers for Disease Control and Prevention, Fort Collins, CO 80521, USA \\ ${ }^{\mathrm{b}}$ Utah Department of Health, Salt Lake City, UT 84113, USA \\ Received 12 October 2008; accepted 9 January 2009
}

\begin{abstract}
Francisella tularensis subsp. tularensis (type A) is subdivided into clades A1 and A2. Human tularemia infections caused by A1 and A2 differ with respect to clinical outcome; A1 infections are associated with a higher case fatality rate. In this study, we develop and evaluate TaqMan polymerase chain reaction (PCR) assays for identification of A1 and A2. Both assays were shown to be specific to either A1 or A2, with sensitivities of 10 genomic equivalents. Real-time PCR results for identification of A1 and A2 were in complete agreement with results obtained by pulsed field gel electrophoresis analysis or conventional PCR when specimens from sporadic tularemia cases and a tularemia outbreak involving both A1 and A2 were tested. In addition, outbreak samples not previously typed to the clade level could be classified as A1 or A2. The assays described here provide new diagnostic tools with a level of sensitivity not previously available for identification of A1 and $\mathrm{A} 2$ infections.

Published by Elsevier Inc.
\end{abstract}

Keywords: Francisella tularensis; Tularemia; Type A, A1, A2; TaqMan

\section{Introduction}

Francisella tularensis is a Gram-negative bacterial pathogen that causes the zoonotic disease tularemia (Ellis et al., 2002). Two subspecies, F. tularensis subsp. tularensis (type A) and F. tularensis subsp. holarctica (type B), are of clinical relevance, and both can cause several distinct presentations of tularemia. Tularemia infections caused by F. tularensis subsp. tularensis are documented only in North America, whereas F. tularensis subsp. holarctica causes infections in North America, Europe, and Asia (Ellis et al., 2002; Sjostedt, 2005). In the United States, an average of 124 human cases of tularemia is reported each year (Centers for Disease Control and Prevention [CDC], 2002). F. tularensis subsp. tularensis has traditionally been considered more virulent than $F$. tularensis subsp. holarctica based on mean lethal dose studies in rabbits (Ellis et al., 2002). Infections caused by F. tularensis subsp tularensis are acquired by arthropod bites (ticks and deer-flies),

\footnotetext{
* Corresponding author. Tel.: +1-970-266-3524; fax: +1-970-494-6631.
}

E-mail address: jpetersen@cdc.gov (J.M. Petersen). handling of infected animal carcasses, and inhalation of infective aerosols. Outbreaks involving $F$. tularensis subsp. tularensis are rare. On Martha's Vineyard, cases caused by this subspecies have been reported between 2000 and 2006, with only two recognized outbreaks occurring in the last 22 years (1978 and 2000) (Feldman et al., 2001, 2003; Matyas et al., 2007).

Historically, F. tularensis subsp. tularensis strains have been considered equivalent with respect to virulence. Molecular methods, specifically multiple locus variable number tandem repeat analysis (MLVA), pulsed field gel electrophoresis (PFGE), and genome sequence comparisons, have separated this subspecies into 2 genetically distinct clades, A1 (also known as A.I and A-east) and A2 (also known as A.II and A-west) (Beckstrom-Sternberg et al., 2007; Farlow et al., 2005; Johansson et al., 2004; Larsson et al., 2007; Molins-Schneekloth et al., 2008; Nubel et al., 2006; Staples et al., 2006; Svensson et al., 2005). Recently, a difference in the severity of human illness caused by $F$. tularensis subsp. tularensis $\mathrm{A} 1$ and $\mathrm{A} 2$ has been reported (Staples et al., 2006). A1 isolates were recovered more frequently from the lung and blood as compared with A2 
isolates. In addition, case fatality rates were shown to differ significantly between infections caused by $\mathrm{A} 1$ and $\mathrm{A} 2$, at $14 \%$ and $0 \%$, respectively. Despite this difference in clinical severity, the only methods currently available for differentiating F. tularensis subsp. tularensis clades A1 and A2 require a recovered isolate (PFGE and MLVA) or are lacking in sensitivity (conventional polymerase chain reaction [PCR] and MLVA) (Farlow et al., 2005; Molins-Schneekloth et al., 2008; Staples et al., 2006).

Here, we develop and evaluate TaqMan PCR assays for the identification of $F$. tularensis subsp. tularensis clades A1 and A2. Two regions of difference (RD), RD-5 and RD-3, previously identified by suppression subtractive hybridization, were used for assay development (Molins-Schneekloth et al., 2008). RD-5 lies within a region spanning both geneencoding regions (hypothetical protein and a pseudogene for methyltransferase) and an intergenic region. It is present in A2 strains and absent from A1 strains. RD-3 lies within a hypothetical protein and is present in A1 strains and absent from A2 strains. The A1 and A2 TaqMan assays demonstrated good sensitivity and specificity. Using samples from sporadic tularemia cases and a 2007 deer-fly-associated tularemia outbreak in Utah in which both A1 and A2 caused disease (Petersen et al., 2008), we show the use of these assays for identification of A1 and A2. This study provides new tools that enhance our ability to investigate $F$. tularensis subsp. tularensis outbreaks as well as offers clinical laboratories and researchers a rapid method for identification of F. tularensis subsp. tularensis A1 and A2.

\section{Materials and methods}

\subsection{Bacterial isolates and DNA preparation}

Representative strains of $F$. tularensis, Francisella novicida, and Francisella philomiragia were grown from frozen stocks on cysteine heart agar with $9 \%$ chocolatized sheep blood (CHAB) at $35{ }^{\circ} \mathrm{C}$ for $48 \mathrm{~h}$, followed by subculture onto CHAB for $24 \mathrm{~h}$ at $35^{\circ} \mathrm{C}$. Other bacterial strains were grown as previously described (Versage et al., 2003). Genomic DNA was isolated using the QIAamp DNA mini kit (Qiagen, Valencia, CA) according to the manufacturer's instructions or as previously described (Kugeler et al., 2006; Versage et al., 2003). Double-stranded DNA concentration was determined using PicoGreen and a NanoDrop Fluorospectrometer (Thermo Fisher Scientific, Waltham, MA). Aliquots of purified DNA were stored at $-20{ }^{\circ} \mathrm{C}$. Previously frozen DNA was verified amplifiable using the 16S rRNA gene.

\subsection{Outbreak specimens}

A total of 20 outbreak-associated specimens from human cases $(n=11)$ and desiccated rabbit carcasses $(n=8)$ were tested. Twelve samples were collected from 11 human tularemia cases; 5 culture-confirmed cases $(5 F$. tularensis isolates) (Petersen et al., 2008), and 6 culture-negative, PCR- positive cases ( $\mathrm{n}=7 ; 5$ wound swabs, 2 lymph node aspirates). The lymph node aspirates were drawn 3 weeks apart from the same patient. Eight bone marrow samples were collected from the rabbit carcasses. DNA was isolated from all 20 specimens as described above (culture-positive samples) or as previously described (Petersen et al., 2008) and tested by real-time PCR using the $F$. tularensis multitarget assay and the F. tularensis subsp. tularensis assay (Kugeler et al., 2006; Versage et al., 2003). Culture-positive specimens were previously identified as either A1 or A2 by PmeI PFGE typing (Petersen et al., 2008). Five culture-negative, PCRpositive specimens were previously identified as either A1 or A2 by conventional PCR (Petersen et al., 2008).

\subsection{TaqMan primers and probes}

Primers and probes were designed using ABI Primer Express Software v2.0 (Applied Biosystems, Foster City, CA) and synthesized by the CDC Biotechnology Core Facility (Atlanta, GA). Before synthesis, BLAST (blastn) analyses were performed to confirm specificity. The primers for the A1 assay were RD5RT-F (5'-CACTATCTTTACTTTAGCTTTGCCACAA-3') and RD5RT-R-2 (5'-TGATCCTTGGCATAAGAAAAAACA-3') and probe RD5RT-P (5' - CTGGACAAAAA" T" ATTATCAAA GATTAACAAGCCTACGC-3'). For the A2-specific assay, primers were RD3RT-F (5'-GACAATCATTTAAGCAAAACGCTACT-3') and RD3RT-R (3'- GCAGGTAATGTAGTTTTAGCAAATGC-5') and probe RD3RT-P (5'-TTCTAGGATAA"T"CATCTGCGATACCGTTGCC-3'). Probes were synthesized with an internal Black Hole Quencher I (bhq1-dT) at the position " $\mathrm{T}$ " and a 6carboxyfluorescein reporter at the $5^{\prime}$ end.

\subsection{PCR conditions}

PCR conditions were optimized using 1 ng of DNA from F. tularensis subsp. tularensis strains MA00-2987 (A1) and WY96-3418 (A2). A total volume of $20 \mu \mathrm{L}$ was used for every PCR reaction. All reactions contained final concentrations of $1 \times$ LightCycler Fast Start DNA master hybridization probe mix (Roche Applied Sciences, Indianapolis, IN), $5 \mathrm{mmol} / \mathrm{L} \mathrm{MgCl} 2,0.75 \mu \mathrm{mol} / \mathrm{L}$ of each A1 primer or 0.5 $\mu \mathrm{mol} / \mathrm{L}$ of each A2 primer, $0.5 \mathrm{U}$ of uracil-DNA glycosylase (Roche), and $0.2 \mu \mathrm{mol} / \mathrm{L}$ probe. For outbreak specimens, the volume of sample tested ranged from 1 to $10 \mu \mathrm{L}$. Thermal cycling conditions were as follows: 1 cycle of $50^{\circ} \mathrm{C}$ for 2 min, 1 cycle of $95^{\circ} \mathrm{C}$ for 10 min, 45 cycles of $95^{\circ} \mathrm{C}$ for 10 $\mathrm{s}$, and $60^{\circ} \mathrm{C}$ for $30 \mathrm{~s}$, followed by 1 cycle of $45^{\circ} \mathrm{C}$ for $5 \mathrm{~min}$. PCR amplification and detection were performed using the LightCycler 1.2 (Roche Applied Sciences). For each PCR run, a negative control (no DNA) and a positive control (1 ng of DNA from either strain MA00-2987 or WY96-3418) were included. $C_{\mathrm{t}}$ values were determined by performing automatic quantification using the 2 nd derivative maximum method with the $y$ axis set to F1/F3 (LightCycler software version 3.5). 


\subsection{Specificity and sensitivity determinants}

Specificity testing was performed using $1 \mathrm{ng}$ of DNA from $F$. tularensis subsp. tularensis clade A1 or A2, F. tularensis subsp. holarctica, F. novicida, F. philomiragia, or other bacterial species. All 46 F. tularensis subsp. tularensis strains were typed by PmeI PFGE as A1 or A2 using the previously described method (Staples et al., 2006). Genome equivalents (GEs) were calculated based on genome sizes of 1892819 and 1898476 bp for $F$. tularensis subsp. tularensis clade A1 strain SCHU S4 and F. tularensis subsp. tularensis clade A2 strain WY96-3418, respectively. One GE

Table 1

Evaluation of specificity using $F$. tularensis subsp. tularensis A1 and A2 isolates from sporadic and outbreak-associated tularemia cases

\begin{tabular}{|c|c|c|c|c|c|c|}
\hline F. tularensis subsp. tularensis $^{\mathrm{a}}$ & CDC accession no. & Source & Year $^{b}$ & Geographic origin & A1 assay $\left(C_{\mathrm{t}} \text { value }\right)^{\mathrm{c}}$ & A2 assay $\left(C_{\mathrm{t}} \text { value }\right)^{\mathrm{c}}$ \\
\hline \multirow[t]{27}{*}{ Clade A1 } & MA00-2987 & Human & 2000 & Massachusetts & 20.87 & - \\
\hline & AR99-3448 & Human & 1999 & Arkansas & 20.57 & - \\
\hline & MO02-1911 & Human & 2002 & Missouri & 21.15 & - \\
\hline & NE03-1457 & Human & 2003 & Nebraska & 21.14 & - \\
\hline & NY04-2565 & Human & 2004 & New York & 21.06 & - \\
\hline & OK01-2528 & Human & 2001 & Oklahoma & 21.12 & - \\
\hline & SCHU S4 & Human & $1940 \mathrm{~s}$ & Ohio & 20.49 & - \\
\hline & SD00-3147 & Human & 2000 & South Dakota & 20.62 & - \\
\hline & VA00-1000 & Human & 2000 & Virginia & 20.52 & - \\
\hline & ND00-0952 & Human & 2000 & North Dakota & 20.62 & - \\
\hline & KS00-0948 & Cat & 2000 & Kansas & 20.92 & - \\
\hline & NC99-3990 & Rabbit & 1999 & North Carolina & 21.00 & - \\
\hline & AR00-0028 & Human & 2000 & Arkansas & 20.73 & - \\
\hline & NC97-3057 & Rabbit & 1997 & North Carolina & 20.35 & - \\
\hline & MO01-1907 & Human & 2001 & Missouri & 20.86 & - \\
\hline & OK00-2731 & Human & 2000 & Oklahoma & 20.75 & - \\
\hline & UT98-3134 & Human & 1998 & Utah & 21.27 & - \\
\hline & NC01-5379 & Cat & 2001 & North Carolina & 20.93 & - \\
\hline & AR98-2146 & Rabbit & 1998 & Arkansas & 21.17 & - \\
\hline & OK00-4337 & Human & 2000 & Oklahoma & 20.72 & - \\
\hline & AR01-1117 & Human & 2001 & Arkansas & 21.13 & - \\
\hline & GA02-5501 & Human & 1982 & Louisiana & 21.22 & - \\
\hline & IL01-3022 & Human & 2001 & Illinois & 20.88 & - \\
\hline & NY04-2787 & Rabbit & 2004 & New York & 21.28 & - \\
\hline & UT07-4262 & Human & 2007 & Utah & 21.21 & - \\
\hline & UT07-4263 & Human & 2007 & Utah & 21.19 & - \\
\hline & UT07-4265 & Human & 2007 & Utah & 20.44 & - \\
\hline \multirow[t]{24}{*}{ Clade A2 } & WY96-3418 & Human & 1996 & Wyoming & - & 18.72 \\
\hline & AZ01-4999 & Human & 2001 & Arizona & - & 19.50 \\
\hline & CA02-0099 & Human & 2002 & California & - & 18.28 \\
\hline & GA02-5453 & Human & 1993 & Wyoming & - & 18.94 \\
\hline & IDO4-2687 & Human & 2004 & Oregon & - & 19.44 \\
\hline & UT02-1927 & Human & 2002 & Utah & - & 19.28 \\
\hline & WY01-3847 & Human & 2001 & Wyoming & - & 18.97 \\
\hline & WY01-3911 & Human & 2001 & Wyoming & - & 19.80 \\
\hline & WY03-1228 & Human & 2003 & Wyoming & - & 20.15 \\
\hline & NM99-0295 & Rabbit & 1999 & New Mexico & - & 20.03 \\
\hline & $\mathrm{CO} 01-2364$ & Cat & 2001 & Colorado & - & 19.02 \\
\hline & CO01-3713 & Rabbit & 2001 & Colorado & - & 19.61 \\
\hline & $\mathrm{CO} 04-2154$ & Rabbit & 2004 & Colorado & - & 19.27 \\
\hline & OR02-0978 & Cat & 2002 & Oregon & - & 19.40 \\
\hline & UT01-2936 & Human & 2001 & Utah & - & 19.50 \\
\hline & NV87-3695 & Human & 1987 & Nevada & - & 19.59 \\
\hline & NM99-1823 & Human & 1999 & New Mexico & - & 20.03 \\
\hline & WY01-3650 & Human & 2001 & Wyoming & - & 19.72 \\
\hline & OR00-3117 & Human & 2000 & Oregon & - & 19.58 \\
\hline & CO81-0728 & Human & 1981 & Colorado & - & 19.63 \\
\hline & AZ87-2825 & Human & 1987 & Arizona & - & 19.47 \\
\hline & CO02-1841 & Cat & 2002 & Colorado & - & 19.65 \\
\hline & UT07-4632 & Human & 2007 & Utah & - & 19.68 \\
\hline & UT07-4633 & Human & 2007 & Utah & - & 19.95 \\
\hline
\end{tabular}

${ }^{a}$ Clade information was known for all isolates by PmeI PFGE genotyping.

${ }^{\mathrm{b}}$ Isolates (not outbreak associated or a reference strain) were obtained from sporadic tularemia cases occurring for a 26-year period.

${ }^{c}$ A negative $C_{\mathrm{t}}$ value (-) represents no logarithmic amplification detected within 41 amplification cycles. 
of either A1 or A2 was estimated at approximately $2 \mathrm{fg}$ of DNA. Tenfold serial dilutions of DNA ranging from 1 to 100000 GEs were prepared in nuclease-free water and tested in duplicate for each assay. Standard curves were generated using the LightCycler software version 3.5.

\subsection{Inhibition testing}

A1 (SCHU S4) or A2 (WY96-3418) DNA was diluted to $1000 \mathrm{GEs}, 100 \mathrm{GEs}$, and $10 \mathrm{GEs}$ and mixed with DNA from the opposing $F$. tularensis subsp. tularensis clade at ratios of $1: 0,1: 1,1: 2,1: 5$, and 1:10. All mixtures of A1 and A2 were tested in duplicate.

\section{Results}

\subsection{Development and optimization}

The A1- and A2-specific assays were targeted against RD-5 and RD-3, respectively. The A1-specific assay targeted RD-5, which is present in A2 and absent from A1. The A2specific targeted RD-3, which is present in A1 and absent from A2. These 2 RDs were chosen for development of TaqMan PCR assays because they showed the most nucleotide variability within the regions flanking the RD. In both cases, the TaqMan probe was designed to hybridize to the junction because this region discriminates A1 from A2. The amplification size for the A1 and A2 PCR products is 101 and $111 \mathrm{bp}$, respectively.

Both assays were optimized for primer concentration, $\mathrm{MgCl}_{2}$ concentration, and annealing temperature (data not shown). The optimal concentration of each primer was determined to be $0.75 \mu \mathrm{mol} / \mathrm{L}$ for the A1-specific assay and $0.5 \mu \mathrm{mol} / \mathrm{L}$ for the $\mathrm{A} 2$-specific assay. A final $\mathrm{MgCl}_{2}$ concentration of $5 \mathrm{mmol} / \mathrm{L}$ was found to give the best results for both assays. An annealing temperature of $60{ }^{\circ} \mathrm{C}$ was optimal for performing both assays simultaneously (data not shown).

\subsection{Specificity and sensitivity}

Specificity of the 2 TaqMan assays was evaluated using DNA from $24 F$. tularensis subsp. tularensis A1 and 22 F. tularensis subsp. tularensis A2 isolates obtained from sporadic tularemia cases occurring in different geographic locations for a 26-year period (Table 1). The A1-specific assay identified all 24 A1 strains with no cross-reactivity to A2 strains. Conversely, the A2-specific assay recognized all 22 A2 strains with no cross-reactivity to A1 strains. In addition, identification of the strains as A1 or A2 by realtime PCR was in complete agreement with PmeI PFGE genotyping, validating the ability of these assays to accurately differentiate $\mathrm{A} 1$ and $\mathrm{A} 2$ (Table 1 ). The $C_{\mathrm{t}}$ value for $1 \mathrm{ng}$ of DNA ranged from 20.35 to 21.28 and from 18.28 to 20.15 for the A1 and A2 assays, respectively (Table 1).

A panel of $20 \mathrm{~F}$. tularensis subsp. holarctica strains, 7 F. novicida strains, 10 F. philomiragia strains (Table 2), and
13 other bacterial species (20 strains total) were also tested for cross-reactivity with the A1 and A2 assays. The other bacterial species included Klebsiella oxytoca, Pseudomonas aeruginosa, Moraxella spp., Haemophilus influenzae, Enterococcus cloacae, Escherichia coli, Acinetobacter spp., Proteus spp., Serratia spp., Streptococcus faecalis, Legionella spp., Yersinia pestis, and Yersinia enterocolitica. No cross-reactivity was detected with any of the Francisella ( $F$. tularensis subsp. holarctica, F. novicida, and F. philomiragia) (Table 2) or other bacterial species tested (data not shown).

Sensitivity testing indicated that both assays reproducibly detected 10 GEs of $F$. tularensis DNA. The average $C_{\mathrm{t}}$ value for the A1 assay for $100000,10000,1000,100$, and 10 GEs was $23.92,27.94,30.97,34.75$, and 38.12 , respectively. The average $C_{\mathrm{t}}$ value for the A2 assay for $100000,10000,1000$, 100, and 10 GEs was 21.52, 25.13, 28.84, 32.26, and 35.71, respectively. For both assays, the $C_{\mathrm{t}}$ value for $1 \mathrm{GE}$ was $>41.00$. Both TaqMan assays showed good linear log correlation with a regression coefficient of 1.00 and a slope of -3.587 for the A1-specific assay and -3.551 for the A2-specific assay (data not shown).

\subsection{Competitive inhibition}

The sensitivity of the A1-specific assay in the presence of A2 DNA and the A2-specific assay in the presence of A1 DNA was tested because degenerate primer binding sites for the respective assays are present in both A1 and A2. The A1-specific assay showed no inhibition in the presence of 5-fold excess A2 DNA; a sensitivity of 10 GEs (average $C_{\mathrm{t}}$ value of 38.15) was maintained under these conditions. When A2 DNA was added at 10 times the concentration of A1 DNA, a slight inhibitory effect was noted; the A1-specific assay displayed a sensitivity of 100 GEs, with an average $C_{\mathrm{t}}$ value of 34.59 . The A2-specific assay showed no signs of inhibition in the presence of 10 times excess A1 DNA; a sensitivity of 10 GEs (average $C_{\mathrm{t}}$ value of 35.46) was maintained under these conditions. Thus, the real-time assays provide identification of $\mathrm{A} 1$ and A2 in the presence of 10-fold excess DNA of the opposing clade, demonstrating the ability of these assays to detect potential A1/A2 coinfections.

\subsection{Evaluation and application using outbreak specimens}

To evaluate the ability of the TaqMan assays to identify F. tularensis subsp. tularensis A1 or A2 infections, we tested DNA extracted from samples collected during a deerfly-associated tularemia outbreak in Utah in 2007. Results for the 5 culture-confirmed human cases obtained with the A1 and A2 TaqMan assays matched those obtained by PmeI PFGE (Table 3). Two isolates were identified as A2 (UT07-4632 and UT07-4633), and 3 isolates were identified as A1 (UT07-4262, UT07-4263, and UT07-4265). Similarly, when 5 bone marrow DNA samples, extracted from rabbit carcasses (UT07-5152, UT07-5156, UT075157, UT07-5159, and UT07-5161) collected at the 
Table 2

Evaluation of specificity using other Francisella strains

\begin{tabular}{|c|c|c|c|c|c|}
\hline Francisella spp. & CDC accession no. & Source & Geographic origin & A1 assay $\left(C_{\mathrm{t}} \text { value }\right)^{\mathrm{a}}$ & $\mathrm{A} 2$ assay $\left(C_{\mathrm{t}} \text { value }\right)^{\mathrm{a}}$ \\
\hline \multirow[t]{20}{*}{ F. tularensis subsp. holarctica } & LVS & Rat & Russia & - & - \\
\hline & KY99-3387 & Human & Kentucky & - & - \\
\hline & AZ00-1324 & Squirrel & Arizona & - & - \\
\hline & IL00-3633 & Human & Illinois & - & - \\
\hline & CN98-5979 & Human & Canada & - & - \\
\hline & MO01-1673 & Human & Missouri & - & - \\
\hline & OH01-3029 & Prairie dog & Ohio & - & - \\
\hline & KY00-1708 & Human & Kentucky & - & - \\
\hline & IN98-3055 & Rat & Indiana & - & - \\
\hline & UT00-2098 & Human & Missouri & - & - \\
\hline & SP98-6120 & Rabbit & Spain & - & - \\
\hline & CO96-1243 & Vole & Colorado & - & - \\
\hline & CA99-0837 & Human & California & - & - \\
\hline & IN00-2758 & Human & Indiana & - & - \\
\hline & NM00-2642 & Human & New Mexico & - & - \\
\hline & SP98-2108 & Human & Spain & - & - \\
\hline & CA99-3992 & Monkey & California & - & - \\
\hline & AZ00-1325 & Rat & Arizona & - & - \\
\hline & JAP5-3-11 & Human & Japan & - & - \\
\hline & KO97-1026 & Human & Korea & - & - \\
\hline \multirow[t]{7}{*}{ F. novicida } & GA99-3548 & Human & Louisiana & - & - \\
\hline & GA99-3549 & Human & California & - & - \\
\hline & GA99-3550 & Water & Utah & - & - \\
\hline & UT01-4992 & Human & Utah & - & - \\
\hline & AS02-0814 & Human & Australia & - & - \\
\hline & FX1 & Human & Texas & - & - \\
\hline & $\mathrm{FX} 2$ & Human & Texas & - & - \\
\hline \multirow[t]{10}{*}{ F. philomiragia } & GA01-2796 & Human & California & - & - \\
\hline & GA01-2799 & Human & Connecticut & - & - \\
\hline & GA01-2800 & Human & Connecticut & - & - \\
\hline & GA01-2801 & Human & New York & - & - \\
\hline & GA01-2802 & Human & California & - & - \\
\hline & GA01-2803 & Human & New Mexico & - & - \\
\hline & GA01-2804 & Human & Virginia & - & - \\
\hline & GA01-2806 & Human & Massachusetts & - & - \\
\hline & GA01-2807 & Human & Unknown & - & - \\
\hline & GA01-2811 & Water & Utah & - & - \\
\hline
\end{tabular}

${ }^{a}$ A negative $C_{\mathrm{t}}$ value (-) represents no logarithmic amplification detected within 41 amplification cycles.

outbreak site, were tested with the A1 and A2 real-time assays, the results matched those obtained using conventional PCR (Table 3). Thus, the A1 and A2 real-time PCR assays provide results in complete agreement with 2 independent methods, PFGE and conventional PCR, demonstrating the ability of these assays to accurately

Table 3

Comparison of results for PmeI PFGE typing and conventional PCR versus A1 and A2 TaqMan assays using outbreak samples

\begin{tabular}{|c|c|c|c|c|c|c|c|}
\hline $\begin{array}{l}\text { Sample } \\
\text { (CDC accession no.) }\end{array}$ & Source & Sample type & $\begin{array}{l}\text { PmeI } \\
\text { PFGE }^{\mathrm{a}}\end{array}$ & $\begin{array}{l}\text { Conventional } \\
\text { PCR }\end{array}$ & $\begin{array}{l}\text { A1 TaqMan assay } \\
\left(C_{\mathrm{t}} \text { value }\right)^{\mathrm{b}}\end{array}$ & $\begin{array}{l}\text { A2 TaqMan assay } \\
\left(C_{\mathrm{t}} \text { value }\right)^{\mathrm{b}}\end{array}$ & $\begin{array}{l}\text { Clade identified } \\
\text { by A1/A2 } \\
\text { TaqMan assay }\end{array}$ \\
\hline UT07-4632 & Human & Isolate & $\mathrm{A} 2$ & $\mathrm{NT}^{\mathrm{c}}$ & - & 19.68 & $\mathrm{~A} 2$ \\
\hline UT07-4633 & Human & Isolate & A2 & NT & - & 19.95 & A2 \\
\hline UT07-4262 & Human & Isolate & A1 & NT & 21.21 & - & A1 \\
\hline UT07-4263 & Human & Isolate & $\mathrm{A} 1$ & NT & 21.19 & - & A1 \\
\hline UT07-4265 & Human & Isolate & $\mathrm{A} 1$ & NT & 20.44 & - & A1 \\
\hline UT07-5152 & Rabbit & Bone marrow & NT & A1 & 23.43 & - & A1 \\
\hline UT07-5156 & Rabbit & Bone marrow & NT & A1 & 26.83 & - & A1 \\
\hline UT07-5157 & Rabbit & Bone marrow & NT & A1 & 18.40 & - & A1 \\
\hline UT07-5159 & Rabbit & Bone marrow & NT & A1 & 19.58 & - & A1 \\
\hline UT07-5161 & Rabbit & Bone marrow & NT & $\mathrm{A} 2$ & - & 21.45 & $\mathrm{~A} 2$ \\
\hline
\end{tabular}

${ }^{\text {a }}$ Data from previously published study (Petersen et al., 2008).

${ }^{b}$ A negative $C_{\mathrm{t}}$ value (-) represents no logarithmic amplification detected within 41 amplification cycles.

${ }^{\mathrm{c}}$ NT represents assays that were not tested. 
Table 4

Identification of A1 and A2 infections in F. tularensis subsp. tularensis PCR-positive, culture-negative specimens

\begin{tabular}{|c|c|c|c|c|c|c|c|}
\hline $\begin{array}{l}\text { Sample } \\
\text { (CDC accession no.) }\end{array}$ & Source & $\begin{array}{l}\text { Specimen } \\
\text { type }\end{array}$ & $\begin{array}{l}\text { F. tularensis } \\
\text { TaqMan PCR }\end{array}$ & $\begin{array}{l}\text { F. tularensis subsp. } \\
\text { tularensis TaqMan PCR }\end{array}$ & $\begin{array}{l}\text { A1 TaqMan Assay } \\
\text { (+ or }-/ C_{\mathrm{t}} \text { value) }\end{array}$ & $\begin{array}{l}\text { A2 TaqMan Assay }{ }^{\mathrm{a}} \\
\text { (+ or }-/ C_{\mathrm{t}} \text { value) }\end{array}$ & $\begin{array}{l}\text { Clade identified using } \\
\text { A1/A2 TaqMan assays }\end{array}$ \\
\hline UT07-6575 & Human & Wound & + & + & $+/ 36.98$ & $-1-$ & A1 \\
\hline UT07-6576 & Human & Wound & + & + & $-1-$ & $+/ 36.83$ & $\mathrm{~A} 2$ \\
\hline UT07-6577 & Human & Wound & + & + & $-1-$ & $+/ 38.55$ & A2 \\
\hline UT07-6578 & Human & Wound & + & + & $+/ 37.00$ & $-/-$ & A1 \\
\hline UT07-6579 & Human & Wound & + & + & $+/ 38.74$ & $-1-$ & A1 \\
\hline UT07-6580 & Human & Lymph node & + & + & $-1-$ & $+/ 33.05$ & $\mathrm{~A} 2$ \\
\hline UT07-6581 & Human & Lymph node & + & + & $-1-$ & $+/ 34.46$ & $\mathrm{~A} 2$ \\
\hline UT07-5153 & Rabbit & Bone marrow & + & + & $+/ 35.96$ & $-1-$ & A1 \\
\hline UT07-5158 & Rabbit & Bone marrow & + & + & $-1-$ & $+/ 38.77$ & $\mathrm{~A} 2$ \\
\hline UT07-5163 & Rabbit & Bone marrow & + & + & $-1-$ & $+/ 35.02$ & $\mathrm{~A} 2$ \\
\hline
\end{tabular}

${ }^{\text {a }}$ A positive $C_{\mathrm{t}}$ value was logarithmic amplification detected within 41 amplification cycles; a negative $C_{\mathrm{t}}$ value was no logarithmic amplification detected within 41 amplification cycles.

identify A1 and A2 infections by a rapid non-laborintensive method (Table 3).

To determine if the A1 and A2 real-time assays could be used for identification of A1 and A2 infections in culturenegative, $F$. tularensis subsp. tularensis PCR-positive samples, we tested DNA from 6 human cases and 3 rabbit carcasses (Table 4). Conventional PCR was not previously able to identify A1 or A2 infections in these specimens because of limits in sensitivity (Petersen et al., 2008). In contrast, the $\mathrm{A} 1$ and $\mathrm{A} 2$ real-time assays were able to identify infections as either A1 or A2 for all 6 human cases; 3 were positive for A1 (UT07-6575, UT07-6578, and UT07-6579) and 3 were positive for A2 (UT07-6576, UT07-6577, UT076580) (Table 4). In addition, 2 independent samples drawn 3 weeks apart from the same patient (UT07-6580 and UT076581) were both positive for $\mathrm{A} 2$. The $\mathrm{A} 1$ and $\mathrm{A} 2$ real-time assays also identified the infecting type A clade in rabbit carcasses; 1 was positive for A1 (UT07-5153) and 2 were positive for A2 (UT07-5158 and UT07-5163). Thus, the real-time assays were able to identify either A1 or A2 as the source of infection in primary samples, even in the absence of a culture.

To look for evidence of A1/A2 coinfection in the outbreak samples, $10 \mu \mathrm{L}$ of purified DNA was tested from the 7 human and 8 rabbit culture-negative, PCR-positive specimens using A1 and A2 real-time assays. No evidence of coinfection was found; all specimens tested positive $\left(C_{\mathrm{t}}\right.$ values ranged from 19.23 to 37.66 ) for either $F$. tularensis subsp. tularensis clade $\mathrm{A} 1$ or $F$. tularensis subsp. tularensis clade A2 under these conditions.

\section{Discussion}

In this study, we developed 2 real-time TaqMan PCR assays for rapid identification of $F$. tularensis subsp. tularensis A1 and A2 infections by targeting genomic regions differing between $\mathrm{A} 1$ and $\mathrm{A} 2$ strains. The 2 real-time assays were shown to be specific for either A1 or A2 and showed no cross-reactivity to other Francisella or other bacterial species tested. The sensitivity of both assays was determined to be 10 GEs, falling in line with the current real-time TaqMan PCR assays used for identification of $F$. tularensis and $F$. tularensis subsps. tularensis and holarctica (Kugeler et al., 2006; Versage et al., 2003).

Identification of A1 and A2 infections by real-time PCR was shown to directly correlate with results obtained by both PFGE genotyping and conventional PCR (Petersen et al., 2008) when specimens from sporadic cases and an outbreak of tularemia were tested. PFGE and conventional PCR were used successfully to describe the 2007 Utah outbreak as the first documented tularemia outbreak involving both A1 and A2 strains; however, limitations in detection were apparent for both assays. PFGE was only useful for culture-positive samples, and conventional PCR had a limit in sensitivity as demonstrated by identification of the $F$. tularensis subsp. tularensis infective clade for only 5 of the 15 PCR-positive, culture-negative samples collected. Here, using the real-time assays, the infecting clade was identified as either A1 or A2 within all 20 (culture-positive and PCR-positive, culturenegative) human and rabbit specimens associated with the outbreak. Thus, the real-time TaqMan PCR assays have the advantage, in comparison with PFGE, MLVA, and conventional PCR, of being not only rapid and gel free but also more sensitive, allowing for identification of A1 and A2 in both culture-positive and culture-negative samples. Both realtime PCR assays show promise for identification of A1 and A2 in primary specimens; however, because primary specimens from only a single outbreak were evaluated in this study, limitations to the data may exist.

Competitive inhibition testing of the $\mathrm{A} 1$ and $\mathrm{A} 2$ real-time assays demonstrated the ability of these assays to detect both A1 and A2 in a single sample. Currently, it is unknown whether coinfections with A1 and A2 may occur in human, animal, or vectors. To date, the only Francisella coinfection studies documented have focused on F. novicida, with studies finding that $F$. novicida can suppress the growth of $F$. tularensis subsp. holarctica strain LVS by as much as 100fold using a rat model (Cowley et al., 1997). The cooccurrence of A1 and A2 infections in a localized deer-fly- 
associated outbreak of tularemia (Petersen et al., 2008) led us to question whether coinfection with A1 and A2 may have occurred during this outbreak. When the outbreak samples were tested with $\mathrm{A} 1$ and $\mathrm{A} 2$ real-time PCR assays, no evidence of coinfection was found. The implications of this finding are unclear but could suggest that coinfection with A1 and A2 does not occur or that the deer-flies propagating the outbreak were only singly infected with either A1 or A2. Because no $F$. tularensis-positive deer-flies were recovered (Petersen et al., 2008), it is not possible to distinguish between these 2 possibilities.

Given that A1 infections are associated with a higher case fatality rate than $\mathrm{A} 2$ infections (14\% fatality rate for A1 infections as compared with $0 \%$ fatality rate for $\mathrm{A} 2$ infections) (Staples et al., 2006), the real-time assays described here provide a new rapid and sensitive diagnostic tool for clinical identification of A1 and A2 infections. In addition, the 2 assays developed offer a rapid, sensitive, and accessible tool for the research community to use for classification of $F$. tularensis subsp. tularensis strains.

\section{Acknowledgments}

The authors would like to thank Dr Marty Schriefer and Dr Rebecca Eisen for valuable discussions and Kiersten Kugeler, Jessica Versage, and Kim Christensen for contributing DNA and outbreak specimens. Claudia MolinsSchneekloth is funded by the American Society for Microbiology and the Coordinating Center for Infectious Diseases as a postdoctoral fellow.

\section{References}

Beckstrom-Sternberg SM, Auerbach RK, Godbole S, Pearson JV, Beckstrom-Sternberg JS, Deng Z, Munk C, Kubota K, Zhou Y, Bruce D, Noronha J, Scheuermann RH, Wang A, Wei X, Wang J, Hao J, Wagner DM, Brettin TS, Brown N, Gilna P, Keim PS (2007) Complete genomic characterization of a pathogenic A.II strain of Francisella tularensis subspecies tularensis. PLoS ONE 2:e947.

Centers for Disease Control and Prevention (2002) Tularemia-United States, 1990-2000. MMWR Morb Mortal Wkly Rep 51:181-184.

Cowley SC, Myltseva SV, Nano FE (1997) Suppression of Francisella tularensis growth in the rat by co-infection with F. novicida. FEMS Microbiol Lett 153:71-74.
Ellis J, Oyston PC, Green M, Titball RW (2002) Tularemia. Clin Microbiol Rev 15:631-646.

Farlow J, Wagner DM, Dukerich M, Stanley M, Chu M, Kubota K, Petersen J, Keim P (2005) Francisella tularensis in the United States. Emerg Infect Dis 11:1835-1841.

Feldman KA, Enscore RE, Lathrop SL, Matyas BT, McGuill M, Schriefer ME, Stiles-Enos D, Dennis DT, Petersen LR, Hayes EB (2001) An outbreak of primary pneumonic tularemia on Martha's Vineyard. $N$ Engl $J$ Med 345:1601-1606.

Feldman KA, Stiles-Enos D, Julian K, Matyas BT, Telford III SR, Chu MC, Petersen LR, Hayes EB (2003) Tularemia on Martha's Vineyard: seroprevalence and occupational risk. Emerg Infect Dis 9:350-354.

Johansson A, Farlow J, Larsson P, Dukerich M, Chambers E, Bystrom M, Fox J, Chu M, Forsman M, Sjostedt A, Keim P (2004) Worldwide genetic relationships among Francisella tularensis isolates determined by multiple-locus variable number tandem repeat analysis. $J$ Bacteriol 186:5808-5818.

Kugeler KJ, Pappert R, Zhou Y, Petersen JM (2006) Real-time PCR for Francisella tularensis types A and B. Emerg Infect Dis 12:1799-1801.

Larsson P, Svensson K, Karlsson L, Guala D, Granberg M, Forsman M, Johnansson A (2007) Canonical insertion-deletion markers for rapid DNA typing of Francisella tularensis. Emerg Infect Dis 13: $1725-1732$.

Nubel U, Reissbrodt R, Weller A, Grunow R, Porsch-Ozcurumez M, Tomaso H, Splettstoesser W, Finke EJ, Tschape H, Witte W (2006) Population structure of Francisella tularensis. J Bacteriol 188: 5319-5324.

Matyas BT, Nieder HS, Telford III SR (2007) Pneumonic tularemia on Martha's Vineyard: clinical, epidemiologic, and ecological characteristics. Ann N Y Acad Sci 1105:351-377.

Molins-Schneekloth CR, Belisle JT, Petersen JM (2008) Genomic markers for differentiation of Francisella tularensis subsp. tularensis A.I and A. II strains. Appl Environ Microbiol 74:336-341.

Petersen JM, Carlson JK, Dietrich G, Eisen RJ, Coombs J, Janusz AM, Summers J, Beard BC, Mead PS (2008) Multiple Francisella tularensis subspecies and clades, tularemia outbreak 2007, Utah. Emerg Infect Dis 14:1928-1930.

Sjostedt AB (2005) Francisella, In: The proteobacteria. Part B. vol. 2. Brenner DJ, Krieg NR, Staley JT, Garrity GM, Eds., vol. 2. SpringerVerlag; New York, NY, pp. 200-210.

Staples JE, Kubota KA, Chalcraft LG, Mead PS, Petersen JM (2006) Epidemiologic and molecular analysis of human tularemia, United States, 1964-2004. Emerg Infect Dis 12:1113-1118.

Svensson K, Larsson P, Johansson D, Bystrom M, Forsman M, Johansson A (2005) Evolution of subspecies of Francisella tularensis. J Bacteriol 187:3903-3908.

Versage JL, Severin DD, Chu MC, Petersen JM (2003) Development of a multitarget real-time TaqMan PCR assay for enhanced detection of Francisella tularensis in complex specimens. J Clin Microbiol 41: 5492-5499. 